\title{
Perbandingan Metode Interval Training dan Continuous Run terhadap Peningkatan Vo2max
}

\author{
Badruzzaman Busyairi ${ }^{\otimes}$, Hamidie Ronald Daniel Ray \\ Program Studi Ilmu keolahragaan, Departemen Pendidikan Kesehatan dan Rekreasi, Fakultas \\ Pendidikan Olahraga dan Kesehatan, Universitas Pendidikan Indonesia, Indonesia
}

\begin{tabular}{l}
\hline Info Artikel \\
\hline Sejarah Artikel: \\
Diterima: Februri-2018 \\
Disetujui: Mei-2018 \\
Dipublikasikan : Mei-2018 \\
\hline Kata Kunci: \\
VO2max, interval training, dan \\
continuous training \\
\hline
\end{tabular}

\begin{abstract}
Abstrak
Tujuan dari penelitian ini adalah apakah ada peningkatan sebagai acuan pembanding bagi pelatih dalam menentukan efektivitas peningkatan VO2max dengan menggunakan metode interval training dan continuous training. Penelitian ini merupakan penelitian Quasi eksperimen. Populasi dalam penelitian ini adalah siswa SSB Bina Muda Sukatani yang terdiri atas 20 siswa usia 15-19 tahun, dengan subjek penelitian di kelompokan menggunakan metode ordinal pairing yang dibagi menjadi dua kelompok masing-masing kelompok 10 orang. Kelompok pertama dilatih menggunakan metode interval training dan kelompok dua menggunakan metode continuous. Desain dalam penelitian ini Two Group Pre-Test Post-Test Design. Instrumen penelitian menggunakan bleep test. Hasil penelitian menunjukkan bahwa uji paired test, sig. 2 tailed sebesar $0,000<0,05$ yang artinya terdapat perbedaan antara nilai sebelum perlakuan dengan setelah perlakuan, (2) uji independent test, sig. 2 tailed sebesar $0,000<0,05$ yang artinya terdapat perbedaan antara interval training dengan continuous training (3) Terdapat kenaikan VO2max pada interval training sebesar $3,59 \mathrm{ml} / \mathrm{kg} / \mathrm{min}$ (4) Terdapat kenaikan VO2max pada continuous training sebesar $1,29 \mathrm{ml} / \mathrm{kg} / \mathrm{min}$ sehingga metode interval training lebih efektif dibandingkan dengan metode continuous training.
\end{abstract}

\begin{abstract}
The purpose of this study is whether there is an improvement as a benchmark for the coach in determining the effectiveness of VO2max improvement by using interval training and continuous training methods. This research is Quasi experiment research. The population in this study are students of SSB Bina Muda Sukatani consisting of 20 students aged 15-19 years, with research subjects in grouping using ordinal pairing method that is divided into two groups of each group of 10 people. The first group was trained using interval training method and group two using continuous method. Design in this study Two Group Pre-Test Post-Test Design. The research instrument used bleep test. The results showed that the paired test, sig. 2 tailed test was 0.000 $<0,05$, meaning that there was difference between the value before treatment and after treatment, (2) independent test test, sig. 2 tailed by 0,000 <0,05, the difference between the training interval and the continuous training (3) There was an increase in VO2max at the training interval of 3.59 $\mathrm{ml} / \mathrm{kg} / \mathrm{min}$ (4) There was a VO2max increase in continuous training of $1.29 \mathrm{ml} / \mathrm{kg} / \mathrm{min}$ so that the interval training method was more effective than with continuous training method.
\end{abstract}

(C) 2018 Universitas Pendidikan Indonesia 


\section{PENDAHULUAN}

Olahraga sangat bermanfaat untuk kesehatan, karena dapat meningkatkan kualitas hidup dan memperlambat kemunduran status kebugaran seseorang akibat penuaan, penyakit, dan lingkungan. Olahraga yang teratur, dapat meningkatkan fungsi dari jantung, pernafasan, dan otot. Olahraga apapun jenisnya tak lepas dari kebutuhan akan kesegaran jasmani yang baik. Salah satu unsur dari kesegaran jasmani adalah daya tahan. Daya tahan adalah kesanggupan jantung dan paru serta pembuluh darah untuk berfungsi secara optimal dalam keadaan istirahat serta latihan untuk mengambil oksigen kemudian mendistribusikannya ke jaringan yang aktif untuk digunakan pada pada proses metabolisme tubuh. Daya tahan ini sering disebut sebagai daya tahan aerobik (Stølen, Chamari, Castagna, \& Wisløff, 2005). Pada dasarnya ada dua macam ketahanan, yaitu aerobik dan anerobik. Ketahanan aerobik mendominasi olahraga yang menuntut energi untuk waktu yang lama dan tidak menimbulkan hutang oksigen, contoh: dayung, sepakbola. Sedangkan ketahanan anerobik terdapat pada olahraga yang menggunakan energi yang banyak dalam waktu yang singkat yang menimbulkan hutang oksigen, contoh: lari sprint, angkat besi.

Olahraga aerobik adalah setiap jenis kegiatan fisik yang dilakukan pada tingkat intensitas sedang untuk jangka waktu tertentu. Dalam sistem aerobik ini bahan bakar di-suplai baik dari karbohidrat maupun dari lemak yang tersimpan di dalam tubuh kita, dengan oksigen sebagai proses konversi (pengubah) energinya". Harsono (2016). Dalam hal ini, oksigen digunakan untuk "membakar" lemak dan gula untuk menghasilkan adenosin trifosfat yang merupakan pembawa dasar dari energi di tingkat sel. Dalam arti harfiah, "aerobic" berarti "dengan oksigen". Yakni penggunaan oksigen dalam pembuatan energi seperti yang dilakukan oleh otot-otot.

Sepak bola merupakan permainan olahraga yang memprioritaskan kemampuan daya tahan aerobik yang baik atau VO2max yang tinggi. Untuk memenuhi tuntutan daya tahan tersebut seorang harus mempunyai energi dalam jumlah banyak. Tuntutan energi dalam jumlah banyak itu akan diproduksi melalui sistem aerobik yang memerlukan oksigen, oleh karena itu tinggi rendahnya daya tahan seorang para pemain tergantung dari tinggi rendahnya kapasitas oksigen maksimal atau VO2max. Tinggi rendahnya VO2max para pemain sangat berpengaruh pada kondisi fisik atau kesegaran jasmani pemain. Seseorang yang memiliki VO2max yang tinggi tidak saja mampu melakukan aktivitas daya tahan dengan baik tetapi lebih dari itu, mereka akan mampu melakukan recovery (pemulihan) kondisi fisiknya lebih cepat dibandingkan dengan orang yang memiliki VO2max yang rendah. Sehingga kemampuan atlet untuk melakukan aktivitas berikutnya bisa lebih cepat dan mampu bertahan dalam jumlah waktu yang lama.

Pengukuran ketahanan daya tahan aerobik dapat dilakukan dengan mengukur nilai komsumsi oksigen maksimal VO2max adalah jumlah terbanyak oksigen yang dapat digunakan dalam suatu latihan yang maksimal, menggunakan seluruh tubuh, dan diukur pada ketinggian yang setara dengan permukaan air laut. Sebelum usia pubertas, anak laki-laki dan perempuan memiliki nilai VO2max yang tidak jauh berbeda, tapi setelah itu anak perempuan jauh tertinggal. Rata-rata remaja perempuan memiliki nilai VO2max antara 15 hingga $25 \%$ lebih kecil dari remaja pria, walaupun terdapat pendapat lain yang menunjukkan perbedaan 20$37 \%$.

Dalam dunia olahraga daya tahan memiliki peran yang sangat penting pada setiap cabang olahraga gerak. Sepak bola merupakan olahraga yang paling dominan dalam penggunaan kekuatan daya tahan. Banyak tim sepak bola memiliki tingkat daya tahan (VO2max) yang rendah. Hal itu disebabkan oleh beberapa faktor diantaranya kurang terprogramnya sistem latihan yang baik, minimnya kejuaraan yang dilaksanakan, latihan yang kurang tepat dalam meningkatkan daya tahan (VO2max). Keunggulan seorang atlet 
terletak pada kemampuan menyediakan oksigen sesuai keperluannya. Atlet yang kebugarannya baik mempunyai nilai $\mathrm{VO} 2$ max yang lebih tinggi dan dapat melakukan aktifitas lebih kuat dari pada atlet yang memiliki daya tahan yang rendah, sehingga unsur VO2max dalam olahraga adalah salah satu faktor yang menentukan.

Untuk meningkatkan VO2max latihan fisik harus dilakukan, peningkatan $\mathrm{VO} 2 \mathrm{max}$ sebaiknya dengan cara program latihan aerobik, karena dengan latihan aerobik sudah ada pembebanan yang meningkatkan jantung maupun paru. Tinggi rendahnya VO2max para pemain sangat berpengaruh pada kondisi fisik atau kesegaran jasmani pemain. Menurut Sukadiyanto (2011) "Peningkatan VO2max menjadi lebih tinggi mulai umur 10 tahun, walau ada yang berpendapat latihan ketahanan tidak terpengaruh pada kemampuan aerobik sebelum usia 11 tahun. Secara umum, kemampuan aerobik turun perlahan setelah usia 25 tahun". Dalam melatih komponen daya tahan diperlukan waktu cukup lama untuk memperoleh perkembangan yang optimal. Namun dalam beberapa pertandingan sering kali selang waktu yang tersedia hanya sedikit. Sehingga diperlukan metode latihan yang efektif dan efesien yang bisa dipakai oleh atlet untuk bisa meningkatkan daya tahan dalam waktu yang tersedia. Metode latihan yang dapat dipakai untuk maksud tertentu adalah metode interval training dan metode continuous training.

Metode interval training merupakan metode yang sering dipakai oleh pelatih dan atlet. Definisi ini dijelaskan oleh Harsono (1988), sebagai berikut " Latihan interval training adalah suatu sistem latihan yang diselingi oleh interval-interval yang berupa masa-masa istirahat". Dari pendapat tersebut dapat dilihat bahwa interval training dapat dilakukan dalam berbagai bentuk seperti citcuit training, interval running, interval swimming. Cara lain yang juga sering dipakai untuk meningkatkan kemampuan daya tahan kardiovaskuler adalah metode continuous training. "Pada umumnya aktivitas dari metode latihan kontinu pemberian bebannya berlangsung lama, panjang pendeknya waktu pembebanan tergantung dari lamanya aktivitas cabang olahraga yang dilakukan". Sukadiyanto (2011). Latihan ini juga sering disebut dengan lari jarak jauh, yang dimaksud dengan latihan ini adalah latihan berlari dengan kecepatan dan jarak yang ditentukan, tanpa waktu istirahat sampai seluruh jarak ditempuh. Fox and Mathews (1993) "Membagi latihan menjadi 2 cara, masing-masing adalah disebut continuous slow running (CSR) dan continuous fastrunning (CFR)".

Latihan CSR biasanya jarak yang harus ditempuh adalah meliputi jarak antara 2-5 kali jarak lomba. Misalnya pelari 1 mil, maka mereka berlatih dengan jarak antara 2-5 mil. Dengan ketentuan bahwa intensitas latihan meliputi $70-75 \%$ HRR atau kirakira $80-85 \%$ HRmax. Sedangkan latihan CFR, adalah latihan lari dengan fase yang lebih cepat dari latihan CSR, serta jarak yang ditempuh lebih pendek dan akibat kelelahan lebih awal dicapai. Misalnya pelari 1 mil, maka mereka berlatih dengan jarak $1 / 4$ mil. Dengan ketentuan bahwa intensitas latihan meliputi $80-90 \%$ HRR atau 85 95\% HRmax.

\section{METODE}

Metode yang digunakan dalam penelitian ini adalah eksperimen. Penelitian eksperimen yang dianggap mempunyai derajat kepastian paling tinggi (tidak mutlak). Peneliti membuat prediksi terhadap penelitian eksperimen. Kondisi diatur sedemikian rupa, perlakuan terhadap objek dilakukan, akibat suatu perlakuan diukur secara cermat, faktor luar yang mungkin berpengaruh dikendalikan, dengan harapan derajat kepastian jawaban semakin tinggi. (Sudjana, N. dan Ibrahim, 2010).

Desain eksperimen Twogrup pretestposttest ini hanya memiliki 2 set data hasil pengukuran yaitu pretest (O1) dan pengukuran posttest (O2). Teknik analisis data yang dipilih tentu saja two sample t-test. Hipotesis yang diuji hanya satu yaitu ada perbedaan antara nilai rerata pretest dan nilai rerata posttest. Desain penelitian Two-grup pretest-posttest ini 
membandingkan antara dua metode interval traning dan continuous. Dalam penelitian ini tes dilakukan sebanyak dua kali yaitu sebelum dan sesudah perlakuan (treatment). Perbedaan antara pretest dan posttest ini diasumsikan merupakan efek dari treatment atau hasil dari perlakuan diharapkan dapat diketahui lebih akurat, karena terdapat perbandingan antara keadan sebelum dan sesudah diberi perlakuan dan diketahui manakah metode yang lebih efektif untuk peningkatan VO2max.

\section{Partisipan}

Partisipan dalam penelitian ini adalah peserta/atlet SSB Bina Muda Sukatani. Jumlah partisipan yang terlibat sebanyak 20 orang dengan usia 15-19 tahun. Pemilihan menggunakan teknik Purposive. Dasar pertimbangan dalam pemilihan partisipan adalah berdasarkan keefektifan waktu/jarak, hal ini memudahkan peneliti untuk dapat memantau partisipan. Selain itu juga pemilihan partisipan berdasarkan keaktifan peserta/atlet SSB Bina Muda Sukatani dalam latihan.

\section{Instrumen}

Instrumen yang digunakan dalam penelitian ini adalah Bleep Test.

\section{Analisis data}

Setelah data tes awal dan tes akhir terkumpul, langkah selanjutnya adalah mengolah data tersebut secara statistik. Peneliti menggunakan SPSS 20 untuk mengolah data yang telah diperoleh. Adapun prosedur langkahlangkah pengolahan data tersebut sebagai berikut :

Pertama mencari mean (rata-rata) dan simpangan baku dengan menggunakan Sample Kolmogorov-Smirnov Test.

Selanjutnya melakukan uji normalitas menggunakan spss 20. Uji normalitas ini bermaksud untuk mengetahui penyebaran dari distribusi data, apakah menyebar secara normal atau tidak. Dalam pengujian normalitas data peneliti menggunakan Sample Kolmogorovsmirnov Test.
Kemudian melakukan Uji Homogenitas. Uji homogenitas ini adalah untuk mengetahui homogen apa tidaknya suatu data. Pada pengujian homogenitas ini peneliti menggunakan Independent Sample $\mathrm{T}$ test yang dilihat pada kolom Levene's Test for Equality of Variances.

Terakhir melakukan uji $\mathrm{t}$ atau uji signifikasi. Dalam pengujian ini terdapat 2 tes uji signifikasi yaitu uji signifikasi peningkatan masing-masing kelompok (interval training dan continuous training) dengan menggunakan Paired Sample Test. Lalu uji signifikasi perbedaan peningkatan hasil kedua kelompok, dimana peneliti menggunakan Independent Sample $t$ test yang bertujuan untuk mengetahui adakah perbedaan peningkatan yang signifikan dari hasil kedua kelompok.Pada bagian ini ungkapan secara jelas metode penelitian yang digunakan, didalamnya termasuk subjek penelitian, instrumen dan teknik analisis.

\section{HASIL DAN PEMBAHASAN}

Berdasarkan hasil pengambilan dan pengolahan data yang telah dilakukan, maka diperoleh temuan Metode Interval training memberikan pengaruh yang signifikan terhadap peningkatan vo2max . Seperti yang dijelaskan oleh Harsono (2016), "Interval training sangat dianjurkan oleh pelatih-pelatih terkenal oleh karena memang hasilnya sangat positif bagi perkembangan daya tahan maupun stamina atlet". Dari penjelasan tersebut dan sejalan dengan hasil penelitian yang didapat maka sistem latihan interval dapat meningkatkan kapasitas VO2max atlet. Adapun peningkatan kenaikan $\mathrm{VO} 2 \mathrm{max}$ pada interval training sebesar $3,6 \mathrm{ml} / \mathrm{kg} / \mathrm{min}$.

Metode Continuous training memberikan pengaruh yang signifikan terhadap peningkatan VO2max. Harsono (2016), "Ada tiga sistem latihan atau basic forms yang dapat menjamin peningkatan daya tahan kardiovaskular, yaitu sistem continuous training, playing with speed, interval training". Jika latihan continuous dilakukan dengan benar dan teratur perkembangan daya tahan akan meningkat, hal ini seperti yang dijelaskan oleh Harsono (2016), 
"Dengan berlatih (latihan kontinu) dengan intensitas $70 \%$ sebanyak tiga sesi per minggu selama beberapa minggu, perkembangan daya tahan akan sangat terasa". Dari penjelasan tersebut dan sejalan dengan hasil penelitian yang diperoleh maka sistem latihan continuous memang dapat meningkatkan kapasitas VO2max atlet. Adapun kenaikan VO2max pada continuous training sebesar $1,3 \mathrm{ml} / \mathrm{kg} / \mathrm{min}$.

Metode interval training lebih baik dibandingkan dengan metode continuous training terhadap peningkatan $\mathrm{VO} 2 \mathrm{max}$.

Dari hasil penelitian yang telah dilakukan dapat dikatakan bahwa terdapat perbedaan pengaruh yang signifikan dari kedua kelompok (interval training dan continuous training) terhadap peningkatan kapasitas VO2max.

Disimpulkan bahwa dengan latihan fisik menggunakan metode latihan interval training dapat meningkatkan VO2max secara signifikan. Dengan intesitas latihan yang tinggi $(70 \%$ dari kemampuan maksimal) yang diselingi oleh istirahat (2-3 menit) membuat peningkatan VO2max lebih signifikan. Keuntungan yang diperoleh dengan menggunakan metode latihan interval jika dibandingkan dengan metode lainnya

Sama halnya dengan interval training, continuous training pun dapat meningkatkan VO2max secara signifikan. Hal ini dikarenakan lari secara terus menerus akan dapat menghasilkan adaptasi aerobik dengan baik. Seperti yang diutarakan oleh Harsono (2016), "Lari terus menerus yang lebih dari 30 menit dengan tempo yang sedang di bawah ambang rangsang anaerobik (anaerobic threshold) akan menghasilkan adaptasi aerobik dengan baik".

Meskipun kedua metode latihan tersebut mempunyai pengaruh yang signifikan terhadap peningkatan VO2max, nyatanya terdapat perbedaan pengaruh yang signifikan diantara latihan interval training dengan continuous training. Perbedaan tersebut adalah dimana interval training memiliki pengaruh yang lebih baik dibandingkan dengan continous training terhadap peningkatan $\mathrm{VO} 2 \mathrm{max}$.

Terlepas dari metode latihan yang diberikan untuk meningkatkan $\mathrm{VO} 2 \mathrm{max}$ ada beberapa faktor lain yang juga dapat menentukan terhadap hasil yaitu seperti pengaturan pola makan dan juga pola istirahat. Untuk itulah kemungkinan peningkatan VO2max akan lebih baik dan maksimal lagi apabila pola makan dan pola istirahat diatur dengan sebaik-baiknya.

Bagian ini memberikan penjelasan mengenai hasil penelitian lapangan (temuan lapangan) yang telah dilakukan. Hasil penelitian ditulis dengan menggunakan narasi. Di dalam penulisan hasil penelitian tidak dianjurkan menggunakan dot points atau teknik penulisan pengabjadan. Bagian pembahasan dapat menggunakan pilihan kata yang lebih sesuai dengan isi pendahuluan

\section{KESIMPULAN}

Berdasarkan hasil analisis data yang diperoleh dan uraian yang telah dikemukakan, maka kesimpulan yang peneliti ambil dari hasil penelitian ini adalah terdapat pengaruh metode Interval Training Terhadap Peningkatan Vo2max pada Tim Sekolah Sepakbola Bina Muda Sukatani Kabupaten Bekasi. Selain itu, terdapat pengaruh Metode Continuous Training terhadap peningkatan Vo2max pada Tim Sekolah Sepakbola Bina Muda Sukatani Kabupaten Bekasi. Penelitian ini menyimpulkan Metode Interval Training lebih baik dibandingkan dengan Metode Continuous Training terhadap peningkatan Vo2max Pada Tim Sekolah Sepakbola Bina Muda Sukatani Kabupaten Bekasi.

Berdasarkan pada hasil penelitian, penulis mempunyai beberapa saran bagi para atlet/pemain cabang olahraga yang berklasifikasi daya tahan disarankan untuk lebih meningkatkan VO2max, karena dalam hal ini pemain/atlet yang memiliki VO2max yang baik akan mampu untuk bekerja atau berlatih dalam waktu yang lama tanpa mengalami kelelahan yang berlebihan dan dampaknya hasil yang dilakukan menjadi lebih baik.Selain itu, bagi rekan mahasiswa yang akan mengadakan penelitian lebih lanjut tentang metode latihan dalam meningkatkan VO2max penulis sarankan untuk meneliti metode latihan lainnya yang juga 
meningkatkan VO2max seperti Fartlek (playing with speed) ataupun meneliti tipe-tipe latihan interval seperti diantaranya long interval training, intermediate interval training, dan short interval training. Untuk diteliti lebih lanjut tipe interval manakah yang lebih baik.

\section{DAFTAR PUSTAKA}

Fox E., L. Mathews D., K. (1993). The Physiological basis of Physical Education and Athletics. 5eds. Iowa: Brown \& Benchmark 41 1-445.

Harsono. (1988). Panduan kepelatihan . Jakarta. KONI.

Harsono. (2016). Latihan kondisi fisik (untuk atlet dan kesehatan). Bandung: FPOK-UPI Bandung

Stølen, T., Chamari, K., Castagna, C., \& Wisløff, U. (2005). Physiology of Soccer. Sports Medicine, 35(6), 501-536. https://doi.org/10.2165/00007256200535060-00004

Sudjana, N. dan Ibrahim. (2010). Penelitian dan Penilaian Pendidikan. Bandung: Sinar Baru Algensindo.

Sukadiyanto. (2011). Pengantar teori dan metodologi melatih fisik. Bandung: Lubuk Agung. 